\title{
Hubungan Depresi dan Sindrom Dispepsia pada Pasien Penderita Keganasan Yang Menjalani Kemoterapi di RSUP DR. M. Djamil Padang
}

\author{
Mona Rahmi Rulianti ${ }^{1}$, Dedy Almasdy ${ }^{2}$, Arina Widya Murni ${ }^{3}$
}

\begin{abstract}
Abstrak
Gangguan psikologi dan sindrom dispepsia (seperti mual dan muntah) merupakan hal yang sering terjadi pada pasien kanker yang menjalani kemoterapi. Penelitian ini bertujuan untuk melihat hubungan depresi dengan sindrom dispepsia yang terjadi pada pasien keganasan yang menjalani kemoterapi. Metode penelitian ini menggunakan rancangan cross sectional dengan menggunakan kuisioner. Didapatkan pasien sebanyak 56 pasien keganasan yang menjalani kemoterapi di bangsal Penyakit Dalam, Bedah dan Obstetri \& Ginekologi RSUP Dr. M. Djamil Padang selama 3 bulan (Desember 2012-Februari 2013). Depresi dinilai dengan wawancara menggunakan kuisioner BDI (Beck Depression Inventory) II. Dispepsia dinilai dengan menggunakan kuisioner pedoman skor dispepsia. Data dianalisis dengan SPSS 17 menggunakan analisis korelasi bivariat Spearman. Koefisien korelasi untuk depresi dan sindrom dispepsia adalah 0,387. Kesimpulan akhir dari penelitian ini adalah ada hubungan yang cukup dan searah $(p<0,01)$ antara depresi dan sindrom dispepsia yang terjadi pada pasien keganasan yang menjalani kemoterapi.
\end{abstract}

Kata kunci: kanker, kemoterapi, depresi, sindrom dispepsia

\section{Abstract}

Psychological disorders and dyspepsia syndromes (such as nausea and vomiting) is a common thing in cancer patients undergoing chemotherapy. This study aims to examine the relationship of depression with dyspepsia syndrome that occurs in patients with malignancies who are undergoing chemotherapy. Methods this study uses crosssectional design using questionnaires. Obtained for 56 patients who underwent chemotherapy malignancy patients in wards Internal Medicine, Surgery and Obstetrics \& Gynecology in Hospital Dr. M. Djamil Padang for 3 months (December 2012-February 2013). Depression was assessed by interview using a questionnaire BDI (Beck Depression Inventory) II. Dyspepsia assessed using questionnaires guidelines dyspepsia score. Data were analyzed with SPSS 17 using bivariate Spearman correlation analysis. The correlation coefficients for depression and dyspepsia syndrome was 0.387. The final conclusion of this study is that there are sufficient and direct relationship $(p<0.01)$ between depression and dyspepsia syndrome that occurs in patients with malignancies who are undergoing chemotherapy.

Keywords: cancer, chemotherapy, depression, dyspepsia syndrome

Affiliasi penulis : ${ }^{1}$ Mahasiswa S2 Farmasi Klinis Unand, ${ }^{2}$ Fakultas Farmasi Unand, ${ }^{3}$ Bagian IImu Penyakit Dalam FK Unand Korespondensi :Program Pascasarjana Fakultas Farmasi, Universitas Andalas. Email: ${ }^{1}$ monagerlonso@yahoo.com Telp: 085263806220

\section{PENDAHULUAN}

Kanker merupakan istilah umum untuk kelompok besar penyakit yang dapat mempengaruhi setiap bagian dari tubuh. Istilah lain yang digunakan adalah tumor ganas dan neoplasma. ${ }^{1}$ Di seluruh dunia, angka kejadian kanker meningkat dengan pesat sehingga merupakan penyebab utama morbiditas dan mortalitas. Diperkirakan 500.000 orang yang tidak diklasifikasikan menurut usia dan jenis kelamin, telah meninggal setiap tahun karena kanker di Amerika Serikat. $^{2}$

Penyakit keganasan (kanker) dan pemberian kemoterapi dapat berpengaruh terhadap fisik maupun emosional pada pasien. ${ }^{3}$ Gangguan pikiran (emosional) merupakan salah satu penyebab terjadinya keluhan dispepsia. ${ }^{4}$ Selain itu, masalah yang sering muncul pada pasien kemoterapi adalah efek samping yang timbul akibat obat-obatan kemoterapi. Efek samping yang sering terjadi pada pasien kemoterapi adalah mual, muntah, dan rasa tidak enak pada perut bagian atas (sindrom dispepsia) yang terjadi pada pasien setelah diberikan kemoterapi. $^{5}$

Efek kemoterapi pada pasien dapat mempengaruhi secara biologis, fisik, psikologis, dan sosial. Efek kemoterapi sangat beragam tergantung kepada obat yang diberikan. ${ }^{6}$ Efek samping yang berat sering timbul pada pasien pasca kemoterapi dan sering kali tidak dapat ditoleransi oleh pasien, bahkan menimbulkan kematian. Frekuensi efek samping paling besar adalah gangguan mual dan muntah. Mual dan muntah dapat memberikan efek samping pada kualitas hidup pasien dimana mereka akan mengalami kesulitan dalam menjalankan aktivitas sehariseharinya. ${ }^{5}$ Walaupun banyak antinausea dan antivomiting yang telah digunakan dalam pengobatan, efek mual dan muntah yang disebabkan oleh kemoterapi masih merupakan penyebab terbesar terhadap perubahan kualitas hidup pasien kanker. Dan juga pengobatan dengan antinausea dan antivomiting memiliki efek yang terbatas dalam hal mengurangi gejala mual dan muntah yang tertunda daripada mual dan muntah akut. ${ }^{7}$

Suatu penelitian meta-analisis di Amerika menyatakan bahwa sekitar $50 \%$ pasien dengan kanker stadium lanjut memenuhi kriteria untuk gangguan 
psikiatri, yang paling umum adalah gangguan penyesuaian $(11-35 \%)$ dan depresi berat $(5-26 \%)^{8}$. Depresi merupakan gejala umum pada pasien kanker yang sulit dideteksi, sehingga konsekuensinya perlu untuk dirawat. Hal ini memburuk selama dalam pengobatan kanker, berlanjut lama setelah akhir terapi dan berpengaruh negatif terhadap kualitas hidup. Pasien kanker yang menjalani kemoterapi biasanya mengalami berbagai gejala sebagai akibat dari penyakit atau dari kemoterapi itu sendiri. Gejala ini mempengaruhi pasien, baik secara fisik maupun emosional dan lebih jauh lagi memberikan pengaruh negatif terhadap pengobatan, prognosis penyakit dan kualitas hidup pasien. ${ }^{2}$ Morrel (1991) menyimpulkan dispepsia merupakan keluhan yang berarti dari pasien-pasien dengan adanya gangguan psikiatri, terutama ansietas, depresi atau ciri kepribadian. ${ }^{9}$

Berdasarkan hal tersebut maka dilakukan penelitian untuk mengetahui hubungan faktor depresi dan sindrom dispepsia pada pasien penderita penyakit keganasan yang menjalani kemoterapi di RSUP DR. M.Djamil Padang serta meningkatkan peran farmasis dalam pelayanan kefarmasian yaitu dengan mengetahui efek samping khususnya sindrom dispepsia yang mungkin terjadi pada pasien dalam menjalani kemoterapi sehingga dapat tercapai kualitas hidup pasien yang lebih baik.

\section{METODE}

Penelitian dilaksanakan selama 3 bulan (Desember 2012 - Februari 2013) di RSUP dr M.Djamil Padang di tiga SMF yaitu Bedah, Penyakit Dalam dan Obstetri \& Ginekologi. Metode penelitian yang digunakan adalah rancangan cross sectional.

Studi cross sectional ini sering juga disebut sebagai studi prevalensi atau survei. Studi cross sectional mengukur variabel dependen dan independen secara bersamaan ${ }^{10}$. Pada penelitian ini variabel independennya adalah pasien keganasan yang menjalani kemoterapi sedangkan variabel dependennya adalah depresi dan sindrom dispepsia. Populasi pada penelitian ini adalah semua pasien keganasan di RSUP dr. M.Djamil Padang. Subjek penelitian yang dipilih adalah semua populasi yang memenuhi kriteria inklusi dan kriteria eksklusi.Kriteria inklusi subjek adalah: pasien keganasan dengan usia $\geq 18$ tahun dan sudah pernah menjalani kemoterapi satu siklus (kemoterapi ke-2 dan seterusnya), memiliki kemampuan untuk mengisi kuisioner. Kriteria eklusi subjek adalah: pasien yang baru pertama kali menjalani kemoterapi (siklus kemoterapi ke-1), pasien yang menderita psikotik, pasien yang mengalami penurunan kesadaran. Selama 3 bulan penelitian, didapatkan subjek sebanyak 56 pasien.

Data diperoleh dari wawancara pasien dan kuisioner. Lembar pengumpul data meliputi : Kuisioner untuk mengukur depresi atau tidaknya pasien. Kuisioner yang digunakan adalah BDI II (Beck Depression Inventory II) versi Bahasa Indonesia. BDI II telah divalidasi sebagai alat pengukur depresi yang sensitif, spesifik dan prediktif. ${ }^{11}$ Kuisioner pedoman skor dispepsia. Skor dispepsia adalah skor untuk menentukan derajat berat ringannya dispepsia. Yang dinilai adalah anoreksia, nausea, rasa cepat kenyang, kembung, muntah dan nyeri perut. ${ }^{12}$

Data dianalisis dengan menggunakan SPSS 17 dengan menggunakan korelasi bivariat Spearman. Uji korelasi bivariat Spearman digunakan untuk mengukur kuat lemahnya hubungan antara dua variabel yaitu variabel derajat depresi dengan variabel derajat sindrom dispepsia pasien keganasan yang menjalani kemoterapi. Korelasi dapat menghasilkan angka positif (+) dan negatif (-). Positif menunjukkan kedua variabel bersifat searah sedangkan negatif menunjukkan kedua variabel bersifat tidak searah. Angka korelasi berkisar antara $0 \mathrm{~s} / \mathrm{d}$ 1. Dengan ketentuan jika angka mendekati 1, hubungan variabel semakin kuat, dan jika angka korelasi mendekati 0 , hubungan korelasi semakin lemah. ${ }^{13}$

\section{HASIL DAN PEMBAHASAN}

Dari penelitian yang telah dilakukan selama 3 bulan (Desember 2012 sampai Februari 2013) di RSUP dr. M. Djamil Padang didapatkan pasien keganasan yang menjalani kemoterapi sebanyak 56 orang. Karakteristik pasien dan parameter dapat dilihat pada tabel berikut.

Tabel 1. Data distribusi pasien keganasan yang menjalani kemoterapi berdasarkan jenis kelamin

\begin{tabular}{lcc}
\hline Jenis Kelamin & $\begin{array}{c}\text { Jumlah } \\
(\mathbf{n}=\mathbf{5 6})\end{array}$ & $\begin{array}{c}\text { Persentase } \\
(\%)\end{array}$ \\
\hline - Laki-laki & 3 & $5,4 \%$ \\
- Perempuan & 53 & $94,6 \%$ \\
\hline
\end{tabular}

Dari penelitian selama 3 bulan didapatkan distribusi pasien laki-laki sebanyak 3 orang $(5,4 \%)$ dan pasien perempuan sebanyak 53 orang $(94,6 \%)$. Dari data ini dapat diketahui, pasien keganasan paling banyak diderita oleh pasien perempuan.

Tabel 2. Data distribusi umur pasien keganasan yang menjalani kemoterapi

\begin{tabular}{lcc}
\hline Umur & $\begin{array}{c}\text { Jumlah } \\
(\mathbf{n}=\mathbf{5 6})\end{array}$ & $\begin{array}{c}\text { Persentase } \\
(\%)\end{array}$ \\
\hline - $<20$ tahun & 1 & $1,8 \%$ \\
$-20-29$ tahun & 4 & $7,1 \%$ \\
- 30-39 tahun & 10 & $17,9 \%$ \\
- 40-49 tahun & 20 & $35,7 \%$ \\
- 50-59 tahun & 16 & $28,6 \%$ \\
- 60-69 tahun & 3 & $5,4 \%$ \\
- 70-79 tahun & 2 & $3,6 \%$ \\
Mean SD & $45,9 \pm 11,8$ & \\
Mode & 48 dan 52 & \\
Min s/d Maks & 18 s.d 72 & \\
& & \\
\hline
\end{tabular}

Dari tabel distribusi umur pasien keganasan, diketahui rata-rata pasien keganasan dalam penelitian ini adalah pada kelompok umur 40-49 tahun, dan kelompok umur yang paling banyak adalah pada umur 48 dan 52 tahun $(35,7 \%)$

Tabel 3. Distribusi derajat depresi pada pasien keganasan yang menjalani kemoterapi

\begin{tabular}{lcc}
\hline Derajat Depresi & $\begin{array}{c}\text { Jumlah } \\
(\mathbf{n = 5 6 )}\end{array}$ & $\begin{array}{c}\text { Persentase } \\
(\mathbf{\%})\end{array}$ \\
\hline - Depresi minimal & 29 & $51,8 \%$ \\
- Depresi ringan & 21 & $37,5 \%$ \\
- Depresi sedang & 6 & $10,7 \%$ \\
- Depresi berat & 0 & $0 \%$ \\
\hline
\end{tabular}


Dari data distribusi derajat depresi pasien keganasan yang menjalani kemoterapi yang dinilai dengan kuisioner BDI II, didapatkan pasien yang mengalami depresi minimal sebanyak 29 orang $(51,8 \%)$, depresi ringan sebanyak 21 orang $(37,5 \%)$, depresi sedang ada 6 orang $(10,7 \%)$, dan tidak didapatkan pasien dengan derajat depresi berat.

Tabel 4. Distribusi derajat dispepsia pada pasien keganasan yang menjalani kemoterapi

\begin{tabular}{lcc}
\hline Derajat Dispepsia & $\begin{array}{c}\text { Jumlah } \\
(\mathbf{n}=\mathbf{5 6})\end{array}$ & $\begin{array}{c}\text { Persentase } \\
(\%)\end{array}$ \\
\hline - Tidak ada keluhan & 10 & $17,9 \%$ \\
- Ringan & 31 & $55,4 \%$ \\
- Sedang & 14 & $25 \%$ \\
- Berat & 1 & $1,8 \%$ \\
\hline
\end{tabular}

Dari data distribusi derajat dispepsia pada pasien keganasan yang menjalani kemoterapi diketahui pasien paling banyak mengalami dispepsia ringan yaitu 31 orang $(55,4 \%)$, diikuti dengan dispepsia sedang sebanyak 14 orang $(25 \%)$, tidak ada keluhan sebanyak 10 orang $(17,9 \%)$ dan dengan keluhan dispepsia berat ada 1 orang $(1,8 \%)$.

Tabel 5. Hubungan derajat dispepsia dengan derajat depresi menggunakan korelasi bivariant Spearman

\begin{tabular}{llc}
\hline & & Derajat depresi \\
\hline Derajat dispepsia & Correlation & .387 \\
& Coefficient & \\
& Sig. (2-tailed) & .003 \\
& $\mathrm{~N}$ & 56 \\
\hline
\end{tabular}

${ }^{* *}$. Correlation is significant at the 0.01 level (2-tailed).

Dalam penelitian ini akan dikaji bagaimana hubungan (korelasi) faktor depresi dengan sindrom dispepsia yang dialami pasien kanker yang menjalani kemoterapi. Analisis dilakukan dengan uji korelasi bivariat Spearman. Hasil pengujian SPSS 17 yang menggunakan korelasi Spearman didapatkan koefisien korelasi Spearman 0,387. Nilai ini menunjukkan korelasi cukup dan bermakna secara statistik $(p<0,01)$ antara dispepsia yang terjadi pada pasien kemoterapi dengan depresi. Nilai korelasi yang positif menunjukkan adanya hubungan yang searah antara terjadinya dispepsia dan depresi pasien kemoterapi.

Penelitian lain yang mendukung penelitian ini seperti yang diteliti Johnsen $R$ dan kawan kawan (1998) mengatakan pada kejadian dispepsia non ulkus dan fungsional menunjukkan hubungan dengan faktor psikologi dan kondisi-kondisi sosial. Demikian juga Haug TT dan kawan kawan (1995) yang menemukan pasien pasien dengan dispepsia fungsional mempunyai tingkat yang lebih tinggi kecemasannya, psikopatologi, depresi dan keluhan somatik. ${ }^{14}$

Dalam penelitian lain mengenai korelasi skor dispepsia dan skor kecemasan di RSUD Prof. DR. Margono Soekarjo Purwokerto mendapatkan adanya korelasi antara skor dispepsia dan skor kecemasan dengan nilai koefisien Spearman 0,775, yang berarti bahwa kekuatan korelasi antara kedua variabel tersebut kuat. ${ }^{15}$ Hasil penelitian ini sesuai dengan hasil penelitian yang dilakukan oleh Chen et al (2006) pada pasien dispepsia fungsional di Taipei Veterans General Hospital yang mengemukakan bahwa kecemasan secara signifikan berpengaruh terhadap pasien dengan dispepsia fungsional. Semakin tinggi tingkat kecemasan seseorang maka semakin tinggi pula tingkat keparahan dispepsia fungsionalnya, dan hal ini berlaku sama baik untuk laki-laki maupun perempuan. Henningsen et al (2003) membenarkan hubungan yang sangat signifikan antara dispepsia fungsional dan irritable bowel syndrome (IBS) dengan kecemasan dan depresi. ${ }^{16}$

Murni (2011) dalam penelitiannya terhadap level kortisol serum pada pasien dispepsia dengan gangguan psikosomatis mendapatkan hasil bahwa penderita sindrom dispepsia dengan gangguan psikosomatik terutama depresi terdapat peningkatan nilai kortisol serum pada pagi hari bermakna secara statistik $(p<0,05)$ dibandingkan dengan kelompok kontrol (tidak mengalami gangguan psikosomatik). ${ }^{17}$ Interaksi faktor psikis dengan gangguan saluran cerna diyakini melalui mekanisme brain - gut - axis. Adanya stimulasi atau stresor psikis mempengaruhi keseimbangan sistem syaraf otonom, mempengaruhi fungsi hormonal, serta sistem imun (psiko - neuroimun - endokrin). Jalur tersebut secara langsung atau tidak langsung, terpisah atau bersamaan dapat mempengaruhi saluran cerna, mempengaruhi sekresi, motilitas, vaskularisasi dan menurunkan ambang rasa nyeri. $^{18}$

Gangguan sekresi pada lambung dapat terjadi karena gangguan jalur endokrin melalui poros hipotalamus - pituitary - adrenal (HPA axis). Pada keadaan ini terjadi peningkatan kortisol dari korteks adrenal akibat rangsangan dari korteks serebri diteruskan ke hipofisis anterior sehingga terjadi pengeluaran hormon kortikotropin. Peningkatan kortisol ini akan merangsang produksi asam lambung dan dapat menghambat Prostaglandin $E$ yang merupakan penghambat enzim adenil siklase pada sel parietal yang bersifat protektif terhadap mukosa lambung. ${ }^{19}$

Dengan demikian akan terjadi gangguan keseimbangan antara peningkatan asam lambung (faktor agresif) dengan penurunan prostaglandin (faktor defensif) sehingga menimbulkan keluhan sebagai sindroma dispepsia. Peninggian kortisol pada penderita dispepsia ini menurut Wehr (1982) didapatkan $9 \%$ pada depresi berat. Penelitian tersebut menyebutkan terdapat peningkatan nilai kortisol pada pasien yang mengalami gangguan psikosomatik seperti depresi. $^{20}$

\section{Keterbatasan Penelitian}

Dalam penelitian ini, terdapat keterbatasan penelitian yaitu tidak memperhatikan jenis jenis antineoplastik, rute pemberian obat yang diberikan serta obat anti mual dan muntah pada pasien keganasan yang menjalani kemoterapi. Faktor jenis antineoplastik dengan tingkat emetogenik yang berbeda-beda serta obat antimual dan muntah dapat mempengaruhi derajat sindrom dispepsia yang dialami pasien dan tentu saja juga dapat mempengaruhi derajat depresi pasien.

\section{KESIMPULAN}

Dari penelitian ini didapatkan kesimpulan bahwa derajat depresi yang banyak dialami pasien keganasan yang menjalani kemoterapi adalah depresi minimal diikuti depresi ringan dan depresi sedang, sedangkan untuk derajat dispepsia yang banyak dialami pasien keganasan yang menjalani kemoterapi adalah dispepsia ringan diikuti dispepsia sedang lalu dispepsia berat. Ada hubungan yang cukup bermakna 
secara statistik dan searah antara depresi dan sindrom dispepsia pada pasien keganasan yang menjalani kemoterapi.

\section{DAFTAR PUSTAKA}

1. World Health Organization. World Health Report 2001. Mental health: new understanding, new hope. Geneva: WHO 2009.

2. Polikandrioti M, Evaggelou E, Zerva S, Zerdila M, Koukoularis D, Kyritsi E. Evaluation of depression in patients undergoing chemotherapy. Health Science Journal. 2008; 2(2): 162-72.

3. Schwartz S, Zahasky K. Psychological aspect of chemotherapy. CME Journal of Gynecologic Oncology. 2008; 13: 7-20.

4. Mudjadid E. Permasalahan Gangguan psikomatik dalam ruang lingkup penyakit dalam. Simposium Gangguan Psikomatik di Bidang Penyakit Dalam. Medan: Juni 2001; 1-8.

5. Perwitasari DA. Pengukuran kualitas hidup pasien kanker sebelum dan sesudah kemoterapi dengan EORTC QLQ-C30 di RSUP Dr. Sardjito Yogyakarta. Majalah Farmasi Indonesia. 2009; 20(2).

6. Carroll JK, Colmar D, Moseley F, Morrow GR, Mustian KM, Pierre PJ, Williams GC Oncologist: Integrative nonpharmacologic behavioral interventions for the management of cancer-related fatigue. 2007.

7. Bassam ARH, Zuraidah BMY. Negative impact of chemotherapy on breast cancer patients QOL - utility of antiemetic treatment guidelines and the role of race. Asian Pacific Journal of Cancer Prevention. 2010; 11:1523-27.

8. Miovic M, Block S. Psychiatric disorders in advanced cancer. Cancer. 2007. October 15; 110(8).

9. Llyod GG. Depression and gastrointestinal and liver disorders in depression and physical illness. Vol-6. England: John Wiley \& Sons; $293-302$

10. Candra B. Metodologi penelitian kesehatan. Jakarta: EGC; 2008.

11. Gendelman N, Snel-Bergeon J, McFann K, Kinney G, Wadwa P, Bishop F, Rewers M, Maahs D. Prevalence and correlates of depression in individuals with and without type 1 diabetes. Diabetes Care. 2009; 32(4).

12. Murni AW. Hubungan depresi dengan infeksi helicobacter pylori serta perbedaan gambaran histopatologi mukosa lambung pada penderita dispepsia dungsional (tesis). Jakarta: Departemen IImu Penyakit Dalam FKUI; 2010.

13. Sarwono J. Panduan cepat dan mudah SPSS 14. Penerbit Andi; 2006.

14. Tarigan CJ. Perbedaan depresi pada pasien dispepsia fungsional dan dispesia organik. Bagian Psikiatri Fakultas Kedokteran Universitas Sumatera Utara 2003.
15. Kusuma NHS, Arinton IG, Paramita $H$. Korelasi skor dispepsia dan skor kecemasan pada pasien dispepsia rawat jalan klinik Penyakit Dalam di RSUD Prof. Dr. Margono Soekarjo Purwokerto. Mandala of Health. 2011; 5(3).

16. Henningsen $P$, Zimmermann $T$, Sattel $H$. Medically unexplained physical symptoms, anxiety, and depression. A meta-analytic review. Psycosom Med. 2003; 65: 528-33.

17. Murni AW. Plasma cortisol levels in dyspepsia with psychosomatic patients. Sub Divisi Bagian Psikosomatis Penyakit Dalam Fakultas Kedokteran Universitas Andalas. Padang. 2011.

18. Zubir N. Diagnosis dan penatalaksanaan dispepsia fungsional. Dalam: Manaf A, Elfizon A, Fauzar, editor (penyunting): Naskah lengkap PIB IPD III. Padang: Bag. Penyakit Dalam FKUA; 2002. hlm. 115-22.

19. Levenstein $S$. A very model of a modern etiology: A biopsychosocial view of peptic ulcer. Psychosomatic Medicine. 2000; (62): $176-83$.

20. Daldiyono H. Tukak stress pada penderita strok, aspek patofisiologi (disertasi). Jakarta: FKUI; 1995. 